\title{
Implementasi Theory of Planned Behavior terhadap Pemasaran Usaha Kecil Menengah melalui E-Commerce
}

\author{
Junianto Tjahjo Darsono*, Erni Susana, Eko Yuni Prihantono \\ Fakultas Ekonomi dan Bisnis, Universitas Merdeka Malang \\ *jtd_58@yahoo.com
}

\begin{abstract}
Theory of Planned Behavior (TPB) has supported relationships for predicting many different people's behaviors. TPB shows that the proximal determinant of will behavior is one's intention to engage in that behavior. Attitudes and subjective norms are suggested to exert its effects of behavior through intention. The TPB model is also developed and was further refined based on the results of the model trials conducted using data collected in Malang. The purpose of this study is to analyze the influence of attitudes, subjective norms, and behavioral control on intentions and the translation process will then occur in the behavior of SMEs in marketing through e-commerce. The population in this study is the SMEs in Malang. The sampling technique is simple random sampling. Data analysis techniques use Structural Equation Modeling (SEM) analysis. The results of this study indicate: 1) attitudes, subjective norms, and behavioral control affect the intention, and 2) the intention variable mediates the effect of attitudes, subjective norms, and behavioral control on the behavior of SMEs in marketing through e-commerce by SMEs in Malang.
\end{abstract}

Keywords: Attitude, Behavioral Control, E-Commerce, Intention, Marketing, Subjective Norms

\section{PENDAHULUAN}

Model teoritis terkemuka yang menjelaskan pengaruh informasi dan motivasi perilaku adalah Theory of Planned Behavior (Ajzen, 1991). Theory of Planned Behavior (TPB) telah mendukung hubungan untuk prediksi banyak perilaku orang yang berbeda (Armitage et al., 2001; Bosnjak et al., 2020). TPB menunjukkan bahwa penentu proksimal perilaku kehendak adalah niat seseorang untuk terlibat perilaku itu. Sikap dan norma subyektif disarankan untuk mengerahkan efeknya perilaku melalui niat. Sikap adalah keseluruhan evaluasi afektif dan instrumental melakukan perilaku oleh individu. Norma subyektif menilai tekanan sosial pada individu untuk melakukan atau tidak melakukan suatu perilaku. Lebih lanjut, TPB mencoba untuk memprediksi perilaku yang tidak sepenuhnya kehendak dengan memasukkan persepsi kontrol atas kinerja perilaku sebagai prediktor tambahan niat dan perilaku (Ajzen, 1991). Perceived Behavioral Control (PBC) adalah persepsi individu tentang sejauh mana kinerja perilaku itu mudah atau sulit sambil mempertahankan motivasi tetap konstan (Ajzen, 1991).

Beberapa tahun terakhir terjadi peningkatan niat dalam mengeksplorasi proses intervensi antara niat perilaku dan perilaku. Teori dominan di daerah penelitian ini, yaitu Theory of Planned Behavior (TPB) (Ajzen, 1991) tidak memberikan perhatian 
khusus pada bagaimana niat dapat menyebabkan tindakan, dan proses psikologis mana yang mungkin terlibat dalam hubungan ini. Teori itu mengemukakan niat untuk melakukan perilaku tertentu adalah yang utama dan penentu penting perilaku masa depan, tetapi juga mengakui bahwa sumber non-motivasi, dalam bentuk kontrol perilaku yang dirasakan, dapat memprediksi perilaku secara langsung jika orang memiliki persepsi realistis tentang kontrol perilaku aktual mereka (Ajzen, 1991). Ulasan dan metaanalisis menyarankan kontrol perilaku yang dirasakan menambah nilai prediktif perilaku (Ajzen, 2020).

Usaha Kecil dan Menengah (UKM) adalah salah satu bidang yang memberikan kontribusi yang signifikan dalam memacu pertumbuhan ekonomi Indonesia. Hal ini dikarenakan daya serap UKM terhadap tenaga kerja yang sangat besar dan dekat dengan rakyat kecil (Kuncoro, 2008). Masalah utama yang dihadapi oleh UKM adalah pemasaran (Kuncoro, 2008). Pemasaran dengan metode konvensional memerlukan biaya tinggi, misalnya membuka cabang baru, ikut pameran, pembuatan dan penyebaran brosur dan sebagainya. Berkembangnya internet menjadi sarana yang efisien untuk membuka jalur pemasaran model baru bagi produk UKM. E-commerce merupakan layanan pemasaran dan penjualan yang dapat dilakukan secara online di internet. Pembeli dapat dengan mudah melihat produk unggulan dan bertransaksi sesuai dengan produk secara elektornik yang dipilihnya kapan dan dimana saja. Penelitian ini dilakukan untuk memecahkan permasalahan pemasaran melalui e-commerce oleh UKM dengan pendekatan model Theory of Planned Behavior (TPB).

Dalam TPB, niat perilaku diasumsikan untuk meringkas kekuatan motivasi yang mempengaruhi berlakunya perilaku tertentu, menunjukkan seberapa besar upaya orang bersedia mengerahkan dalam perencanaan diberlakukannya perilaku (Ajzen, 1991). Niat biasanya mencakup sekitar 20\%-40\% dari varians dalam perilaku sosial dan kesehatan dalam prospektif studi (Loren et al., 2020). Meskipun persentase ini tidak kecil, ini menunjukkan bahwa sejumlah orang tidak memberlakukan niat positif mereka untuk melakukan perilaku tertentu. Misalnya dalam hal tujuan/niat bersaing, kurangnya pengetahuan tentang bagaimana memenuhi tujuan, kesulitan untuk memulai, atau melupakan niat menjadi alasan tidak melakunya. Meskipun sejumlah alasan metodologis dapat menjelaskan untuk daya prediksi perilaku karena kurang sempurnanya niat (Sutton, 1998), temuan lain menentang gagasan bahwa proses motivasi memberikan penjelasan yang memadai tentang perilaku, dan menunjukkan bahwa proses lain dapat beroperasi bersama dengan motivasi. Dengan kata lain, hanya berniat untuk melakukan suatu perilaku tidak cukup memberi dorongan untuk berperilaku dalam banyak kasus (Ajzen et al., 2013).

Konsep niat implementasi, yang berakar dalam teori pengaturan diri, telah diusulkan sebagai proses mediasi untuk menjelaskan perbedaan tersebut (Zemore, et al., 2014). Teori pengaturan diri tentang mencapai tujuan memperhatikan bagaimana orang berencana untuk mengatasi masalah yang terjadi menuju arah ke pencapaian tujuan, mengingat bahwa mereka berkomitmen untuk tujuan tertentu. Ide dasarnya berasal dari gagasan bahwa orang cenderung membentuk niat kapan saja mereka berharap bahwa perilaku tertentu akan sulit dilakukan melakukan dan, lebih lanjut, bahwa cara ini sendiri dapat memicu sejumlah proses pengaturan diri yang memungkinkannya untuk menerjemahkan niat menjadi tindakan (Gollwitzer et al., 1998). Dalam teori fase aksi, perbedaan dibuat antara deliberatif fase, yang berkaitan dengan motivasi, dan fase implementasi, yang berkaitan dengan kemauan (Gollwitzer, 1999).

Dalam fase sebelumnya, niat tujuan dibentuk, berdasarkan kriteria kelayakan dan keinginan, dan mirip dengan proses membentuk niat perilaku berdasarkan sikap, norma subyektif dan persepsi kontrol 
perilaku dalam TPB. Fase kedua berkaitan dengan pemilihan tindakan yang relevan untuk diambil untuk memulai pada rute ke pelaksanaan perilaku melalui pembentukan rencana spesifik dalam hal kapan, di mana dan bagaimana bertindak, yaitu pembentukan niat implementasi. Jadi orang pertama yang memutuskan apakah mencoba untuk mencapai suatu tujuan atau mencoba untuk melakukan perilaku, dan telah membentuk niat tujuan positif yang menyiratkan komitmen atau kewajiban untuk mencapai tujuan atau menjalankan aksi. Selanjutnya, yang lebih penting niat tujuan adalah, semakin besar kemungkinan orang akan membentuk niat implementasi dalam pelayanan tujuan, dan lebih mungkin bahwa tujuannya akan tercapai (La Barbera et al., 2020).

Studi empiris membuktikan kegunaan pembentukan niat implementasi dalam proses penerjemahan niat perilaku (atau tujuan) menjadi perilaku aktual kinerja (atau pencapaian sasaran) (Gollwitzer et al., 1998). Misalnya, Gollwitzer et al. (1998) meminta peserta untuk menulis laporan tentang bagaimana mereka menghabiskan liburan Natal mereka dan mengembalikannya dalam waktu periode yang ditentukan. Separuh peserta diperintahkan untuk membentuk niat implementasi dengan meminta untuk menentukan kapan dan di mana mereka bermaksud menulis laporan, sedangkan setengah dari subyek lainnya tidak menerima instruksi ini. Proporsi peserta yang mengembalikan laporan mereka dalam periode waktu kritis lebih tinggi di antara mereka yang telah membentuk niat implementasi daripada di antara mereka yang tidak diperintahkan untuk melakukannya. Hasil ini telah direplikasi dalam serangkaian percobaan yang dilaporkan oleh Gillholm et al. (2001). Model TPB juga dikembangkan oleh Darsono (2018, 2019) selanjutnya disempurnakan berdasarkan hasil uji coba model yang dilakukan dengan menggunakan data yang dikumpulkan di Kota Malang.

Berdasarkan uraian di atas, penelitian ini bertujuan untuk menguji apakah sikap, norma subyektif, dan kontrol keperilakuan berpengaruh terhadap niat, dan selanjutnya akan terjadi proses penerjemahan menjadi perilaku aktual. Adapun kerangka konseptual dalam penelitian ini dapat dilihat pada Gambar 1 berikut ini.

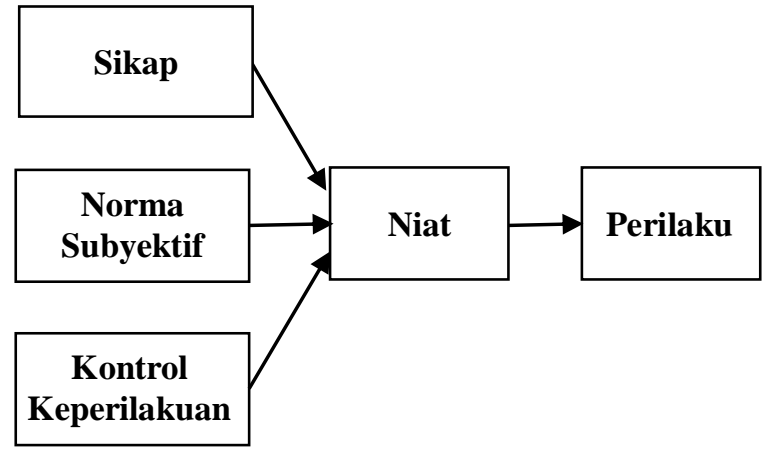

Gambar 1. Kerangka Konseptual Penelitian

\section{Hipotesis}

Berdasarkan uraian tersebut diatas, maka hipotesis dalam penelitian ini adalah:

$\mathrm{H}_{1}$ : Sikap berpengaruh signifikan terhadap niat.

$\mathrm{H}_{2}$ : Norma subyektif berpengaruh signifikan terhadap niat.

$\mathrm{H}_{3}$ : Kontrol keperilakuan berpengaruh signifikan terhadap niat.

$\mathrm{H}_{4}$ : Niat berpengaruh signifikan terhadap perilaku.

$\mathrm{H}_{5}$ : Sikap, norma subyektif, dan kontrol keperilakuan berpengaruh signifikan terhadap perilaku dan niat sebagai pemediasi.

\section{METODE}

Penelitian bertujuan untuk mengimplementasikan model Theory of Planned Behavior dalam pemasaran melalui e-commerce oleh UKM di Kota Malang dilakukan dengan menyusun model struktural mengggunakan Structural Equation Modeling (SEM) dan menempatkan niat sebagai variabel intervening. Daerah penelitian adalah Kota Malang, dengan alasan daerah tersebut merupakan kota terbesar kedua di Jawa Timur, kota pendidikan dan kota pariwisata. Populasi dalam penelitian ini adalah pelaku UKM yang berdomisili di Kota Malang. Berdasar data di Dinas Koperasi dan UKM 
Kota Malang, total ada 2.764 UKM binaan. Namun, baru 880 unit yang tersertifikasi, atau sekitar 32 persen. Besar sampel dalam penelitian ini menggunakan rumus jumlah indikator dikalikan $(5-10)=13 \times 10=130$. Sedangkan teknik pengambilan sampling adalah Simple Random Sampling.

Pengolahan data dilakukan dengan mengelompokkan jawaban sesuai dengan tipe pertanyaan. Dari jawaban tersebut kemudian ditabelkan dan diuji dengan uji validitas dengan teknik Product Moment dan uji reliabilitas dengan metode Alpha Cronbach, kemudian dilakukan analisis variabel sikap, norma subyektif, kontrol keperilakuan, niat, dan perilaku.

Pada tahap ini masih terjadi sebaran terhadap faktor-faktor yang mempengaruhi kondisi di atas, untuk itu diperlukan identifikasi lebih rinci sehingga dapat dikelompokkan sesuai dengan tingkat pengaruhnya. Dengan menggunakan analisis Structural Equation Modelling (SEM), akan jelas hubungan serta pengaruh antara satu sama lain dari berbagai variabel yang ada.

Keluarannya berupa pemodelan yang dapat mengukur pengaruh sikap, norma subyektif, dan kontrol keperilakuan terhadap perilaku serta niat sebagai pemediasi. Tahapan pemodelan SEM: 1) Pengembangan model berbasis teori, 2) Menyusun diagram SEM untuk menyatakan hubungan kausalitas, 3) Menterjemahkan diagram SEM ke dalam persamaan, 4) Memilih matriks input dan estimasi model, 5) Menilai masalah identifikasi, 6) Evaluasi kriteria goodness of fit, 7) Interpretasi dan modifikasi model, dan 8) Pengujian hipotesis.

Solimun (2002) menjabarkan bahwa pengukuran Goodness of Fit untuk outer model dengan indikator reflektif dievaluasi dengan convergent dan discriminant validity, dan untuk keseluruhan indikator, menggunakan composite reliability. Evaluasi ini berupa kalibrasi instrumen yaitu dengan pemeriksaan validitas dan reliabilitas instrumen dari hasil uji coba (try out). Convergent validity yang dimaksud disini adalah korelasi antara skor indikator reflektif dengan variabel latennya, dengan loading 0,5 sampai 0,6 dianggap cukup, pada jumlah indikator per konstruk tidak besar, yaitu antara 3 sampai 7 indikator. Sedangkan discriminant validity merupakan pengukuran indikator reflektif berdasar cross loading dengan variabel latennya. Cross loading setiap indikator dikatakan valid jika nilainya lebih besar bila dibandingkan dengan nilai cross oading dari variabel laten lainnya. Atau dapat pula dengan membandingkan nilai square root average variance extracted (AVE) setiap konstruk dengan korelasi antar konstruk dalam model. AVE dikatakan mempunyai discriminant validity yang baik jika nilainya lebih besar dari korelasi seluruh konstruk lainnya. Direkomendasikan bahwa nilai pengukuran harus lebih besar dari 0,50. Dikemukakan pula bahwa composite reliability adalah kelompok indikator yang mengukur sebuah variabel. Sebuah variabel dikatakan memiliki komposit yang baik jika memiliki composite reliability $\geq 0,7$ walaupun bukan nilai absolute.

\section{HASIL DAN PEMBAHASAN \\ Hasil Uji Validitas dan Reliabilitas Instrumen}

Berdasarkan pengolahan data terlihat dari 38 item pernyataan yang diuji, semua item pernyataan memiliki nilai koefisien korelasi positif dan lebih besar dari $r_{\text {tabel, }}$ serta probabilitasnya lebih kecil dari $\alpha=5 \%$, artinya ada hubungan yang signifikan antara skor masing-masing item pernyataan dengan skor total. Korelasi yang signifikan menunjukkan bahwa indikator memang benar-benar dapat digunakan untuk mengukur item pernyataan yang akan diukur, dengan kata lain instrumen yang digunakan valid dengan demikian dapat dipakai dalam penelitian.

Hasil pengujian reliabilitas dapat dinyatakan bahwa semua variabel yang diteliti dinyatakan reliabel karena nilainya lebih besar dari 0,6. Kesimpulan yang dapat diambil bahwa nilai reliabilitasnya dikategorikan sangat tinggi karena berada pada kisaran di atas 0,8. 


\section{Hasil Analisis Deskriptif}

Persepsi terhadap sikap memiliki skor rata-rata 3,21, menunjukkan kecenderungan setuju. Rata-rata skor tertinggi pada indikator evaluasi pentingnya atribut dari produk sebesar 3,30 dan terendah pada indikator kepercayaan terhadap atribut yang dimiliki produk sebesar 3,13. Artinya sikap pelaku UKM merespon pada tingkat sedang terhadap niat dan perilaku dalam pemasaran melalui e-commerce.

Persepsi terhadap norma subyektif memiliki skor rata-rata 3,59 menunjukkan kecenderungan setuju. Rata-rata skor tertinggi pada indikator motivasi yang sejalan dengan kelompok acuan sebesar 3,59 dan terendah pada indikator kepercayaan normatif kelompok acuan untuk melakukan perilaku tertentu sebesar 3,58. Dengan demikian dapat dimaknai bahwa subyektifitas pemasaran melalui e-commerce lebih bersumber pada adanya motivasi yang ada di diri konsumen dibandingkan dengan kepercayaan normatif dari kelompok acuan.

Persepsi terhadap kontrol keperilakuan memiliki skor rata-rata 3,16 menunjukkan kecenderungan setuju. Rata-rata skor tertinggi pada indikator kekuatan faktor yang mendorong atau menghalangi perilaku sebesar 3,17 dan terendah pada indikator keyakinan faktor yang mendorong atau menghalangi perilaku sebesar 3,14. Dengan demikian dapat dimaknai bahwa faktor kekuatan yang mendorong atau menghalangi dalam pengendalian berperilaku niat dalam pemasaran melalui e-commerce lebih besar daripada keyakinan faktor yang mendorong atau menghalangi perilaku dalam pemasaran melalui e-commerce.

Persepsi terhadap niat memiliki skor rata-rata 3,32 menunjukkan kecenderungan setuju. Rata-rata skor tertinggi pada indikator niat eksploratif sebesar 3,48 dan terendah pada indikator niat tradisional sebesar 3,13. Dengan demikian dapat disimpulkan bahwa pelaku UKM merespon niat eksploratif dalam pemasaran melalui e-commerce melebihi niat tradisional, karena lebih mengutamakan selalu mencari informasi mengenai tentang pemasaran melalui $e$ - commerce yang memberikan layanan terbaik daripada merencanakan pemasaran melalui e-commerce.

Persepsi terhadap perilaku memiliki skor rata-rata 3,58 menunjukkan kecenderungan setuju. Rata-rata skor tertinggi pada indikator memilih sebesar 3,55 dan terendah pada indikator waktu sebesar 3,26 . Dengan demikian dapat disimpulkan bahwa perilaku pemasaran melalui $e$ commerce oleh pelaku UKM di Kota Malang lebih mengedepankan memilih pemasaran melalui e-commerce dibandingkan dengan waktu pemasaran melalui $e$-commerce.

\section{Hasil Analisis Inferensial}

Evaluasi Model Persamaan Struktural menunjukkan hasil sebagai berikut:

1. Evaluasi Normalitas Univariate dan Multivariate

Hasil selengkapnya dapat diketahui bahwa secara univariate (per indikator) maupun multivariate nilai critical ratio berada pada interval $-2,58<\mathrm{CR}<2,58$. Dengan demikian seluruh data baik univariate maupun multivariate berdistribusi normal.

2. Evaluasi Outlier Univariate dan Multivariate

Berdasarkan hasil perhitungan diketahui bahwa Z score seluruh indikator berada di interval $-4,00$ sampai 4,00, artinya seluruh data pada seluruh indikator tidak terkena outlier.

3. Analisis Faktor Konfirmatori

Analisis faktor konfirmatori dilakukan bertujuan untuk mengkonfirmasi setiap indikator yang sudah dibuat berdasarkan penelitian terdahulu maupun teori yang sudah ada dapat digunakan untuk menjelaskan konstruk sikap, norma subyektif, kontrol keperilakuan, kecerdasan spiritual, niat dan perilaku.

\section{Loading Factor}

Besarnya loading factor pada kedua indikator yaitu: kepercayaan terhadap atribut yang dimiliki produk dan evaluasi pentingnya atribut produk tersebut adalah di atas 0,5 , maka kedua indikator tersebut dapat 
digunakan untuk mengukur konstruk sikap. Berdasarkan penghitungan, diperoleh nilai reliabilitas konstruk sikap sebesar 0,991, artinya reliabilitas konstruk sikap sebesar $91,1 \%$.

Besarnya loading factor pada kedua indikator yaitu: kepercayaan normatif kelompok acauan untuk melakukan perilaku tertentu dan motivasi yang sejalan dengan kelompok acuan adalah di atas 0,5, maka kedua indikator tersebut dapat digunakan untuk mengukur konstruk norma subyektif. Berdasarkan penghitungan, diperoleh nilai reliabilitas konstruk norma subyektif sebesar 0,916, artinya reliabilitas konstruk norma subyektif sebesar 91,6\%.

Besarnya loading factor pada kedua indikator yaitu: keyakinan faktor yang mendorong atau menghalangi perilaku dan kekuatan faktor yang mendorong atau menghalangi perilaku adalah di atas 0,5 , maka kedua indikator tersebut dapat digunakan untuk mengukur konstruk kontrol keperilakuan. Berdasarkan penghitungan, diperoleh nilai reliabilitas konstruk kontrol keperilakuan sebesar 0,935, artinya reliabilitas konstruk kontrol keperilakuan sebesar 93,5\%.

Besarnya loading factor pada keempat indikator yaitu: niat tradisional, niat referensial, niat preferensial, dan niat eksploratif adalah di atas 0,5 , maka keempat indikator tersebut dapat digunakan untuk mengukur konstruk niat. Berdasarkan penghitungan, diperoleh nilai reliabilitas konstruk niat sebesar 0,846, artinya reliabilitas konstruk niat sebesar $84,6 \%$.

Besarnya loading factor pada ketiga indikator yaitu: waktu, memilih, dan memanfaatkan adalah di atas 0,5, maka ketiga indikator tersebut dapat digunakan untuk mengukur konstruk perilaku. Berdasarkan penghitungan, diperoleh nilai reliabilitas konstruk perilaku sebesar 0,948, artinya reliabilitas konstruk perilaku sebesar

\section{Evaluasi Kriteria Kelayakan Model (Goodness of Fit Model)}

Structural Equation Modeling (SEM) digunakan untuk menguji berbagai hubungan dalam suatu model. Disamping itu juga untuk menganalisis, mengevaluasi validitas, dan kausalitas antar variabel dari model yang bisa dilihat pada Gambar 2 .

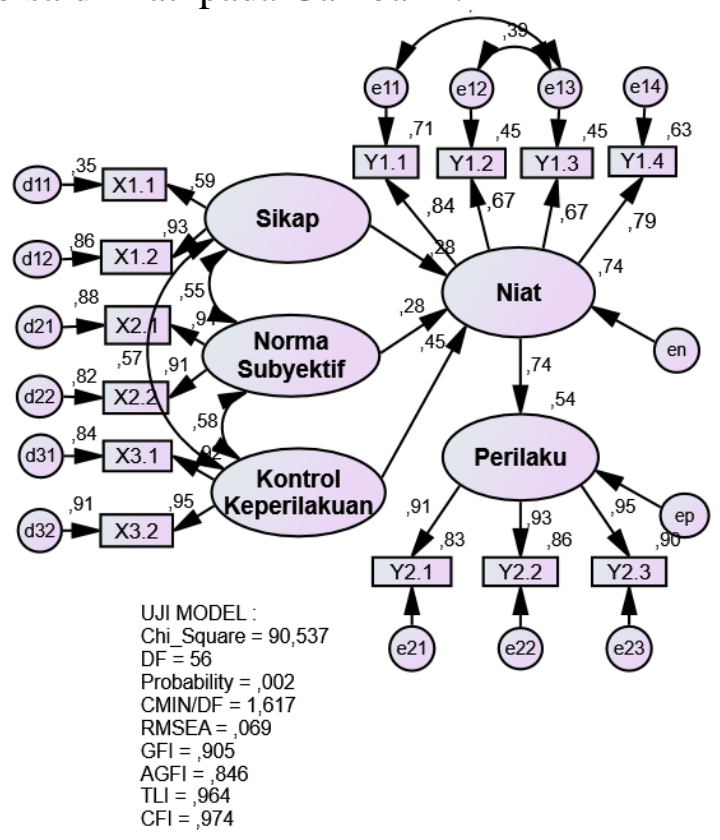

Gambar 2. Hasil Model Struktural

Hasil uji kelayakan model menunjukkan bahwa ringkasan hasil yang diperoleh dalam analisis dan nilai yang direkomendasikan untuk mengukur kelayakan model. Hampir seluruh kriteria memenuhi rekomendasi yang disarankan, kecuali pada hasil uji chi square dan nilai probabilitas. Hair et al. (2010) secara khusus memberikan perkecualian terhadap hasil uji chi square bahwa pada sampel di bawah 250 sampel dan jumlah indikator 1230 hasil uji statistik yang signifikan tetap mendukung fit model dengan syarat nilai CFI dan TLI lebih dari 0,90 dan RMSEA kurang dari 0,08. Nilai GFI, AGFI, CMIN/DF, RMSEA, CFI dan TLI juga menunjukkan hasil yang diperoleh dalam analisis dan nilai yang direkomendasikan untuk mengukur kelayakan model, sehingga hasil evaluasi model ini bisa diterima, dan menjadi model akhir untuk dilakukan interpretasi dan uji hipotesis.

\section{Persamaan Struktural}

Hubungan kausalitas yang dikembangkan dalam hipotesis pada model 
ini diuji dengan hipotesis nol yang menyatakan bahwa koefisien regresi antara hubungan dua konstruk adalah tidak berbeda dengan nol melalui uji-t seperti yang ada dalam analisis regresi. Pengujian hipotesis pada model struktural yang berhubungan dengan hasil uji koefisien regresi pada setiap jalur yang dihasilkan yang dijelaskan pada Tabel 1.

Tabel 1. Hasil Uji Koefisien Regresi Pengaruh Antar Variabel

\begin{tabular}{|c|c|c|c|c|c|}
\hline \multicolumn{2}{|c|}{ Pengaruh } & \multirow{2}{*}{$\begin{array}{l}\text { Koef. } \\
\text { Baku }\end{array}$} & \multirow{2}{*}{ C.R. } & \multirow{2}{*}{ Nilai $p$} & \multirow{2}{*}{ Ket. } \\
\hline Dari & $\mathrm{Ke}$ & & & & \\
\hline Sikap & Niat & 0,176 & 2,712 & ,007 & Sig. \\
\hline $\begin{array}{l}\text { Norma } \\
\text { Subyektif }\end{array}$ & Niat & 0,191 & 3,231 & ,001 & Sig. \\
\hline $\begin{array}{l}\text { Kontrol } \\
\text { Keperilakuan }\end{array}$ & Niat & 0,201 & 4,882 & ,000 & Sig. \\
\hline Niat & Perilaku & 0,729 & 8,711 & ,000 & Sig. \\
\hline
\end{tabular}

Hasil structural model (model struktural) masing-masing variabel penelitian adalah sebagai berikut:

$$
\begin{aligned}
& \mathrm{Y}_{1}=0,176 \mathrm{X}_{1}+0,191 \mathrm{X}_{2}+0,201 \mathrm{X}_{3} \\
& \mathrm{Y}_{2}=0,729 \mathrm{Y}_{1}
\end{aligned}
$$

Persamaan pertama, faktor penentu niat ada tiga yaitu sikap, norma subyektif, dan kontrol keperilakuan. Ketiga penentu ini bertanda positif, artinya sikap, norma subyektif, dan kontrol keperilakuan akan mendorong niat pelaku UKM dalam melakukan pemasaran melalui e-commerce.

Persamaan kedua, faktor penentu perilaku ada satu yaitu niat. Faktor penentu ini bertanda positif, artinya niat akan mendorong perilaku pelaku UKM dalam melakukan pemasaran melalui e-commerce.

\section{Pengujian Hipotesis}

Hasil pengujian hipotesis menunjukkan hasil sebagai berikut:

1. Pengujian Hipotesis 1

Koefisien regresi dari pengaruh sikap terhadap niat bernilai 0,176 dengan C.R. sebesar 2,712 dan $p$-value $=0,007$ (nilai probabilitas lebih kecil dari 0,05) memberikan keputusan adanya pengaruh positif dan signifikan dari sikap terhadap niat. Dengan demikian, dari hasil uji statistik telah diperoleh bukti bahwa sikap mempunyai pengaruh signifikan terhadap niat dalam pemasaran melalui e-commerce oleh UKM di Kota Malang.

2. Pengujian Hipotesis 2

Koefisien regresi dari pengaruh norma subyektir terhadap niat bernilai 0,191 dengan C.R. sebesar 3,231 dan $p$-value $=$ 0,001 (nilai probabilitas lebih kecil dari 0,05) memberikan keputusan adanya pengaruh positif dan signifikan dari norma subyektif terhadap niat. Dengan demikian, dari hasil uji statistik telah diperoleh bukti bahwa norma subyektif berpengaruh signifikan terhadap niat dalam pemasaran melalui e-commerce oleh UKM di Kota Malang.

3. Pengujian Hipotesis 3

Koefisien regresi dari pengaruh kontrol keperilakuan terhadap niat bernilai 0,201 dengan C.R. sebesar 4,882 dan $p$-value= 0,000 (nilai probabilitas lebih kecil dari $0,05)$ memberikan keputusan adanya pengaruh positif dan signifikan dari kontrol keperilakuan terhadap niat. Dengan demikian, dari hasil uji statistik telah diperoleh bukti bahwa kontrol keperilakuan berpengaruh signifikan terhadap niat dalam pemasaran melalui e-commerce oleh UKM di Kota Malang.

4. Pengujian Hipotesis 4

Koefisien regresi dari pengaruh niat terhadap perilaku bernilai 0,729 dengan C.R. sebesar 8,711 dan $p$-value $=0,000$ (nilai probabilitas lebih kecil dari 0,05) memberikan keputusan adanya pengaruh positif dan signifikan dari niat terhadap perilaku. Dengan demikian, dari hasil uji statistik telah diperoleh bukti bahwa niat mempunyai pengaruh signifikan terhadap perilaku dalam pemasaran melalui e-commerce oleh UKM di Kota Malang.

5. Pengujian Hipotesis 5

Berdasarkan hasil pengujian hipotesis 1 , 2, 3, dan 4 diyatakan bahwa masingmasing sikap, norma subyektif, dan kontrol keperilakuan berpengaruh signifikan terhadap niat. Sedangkan niat berpengaruh signifikan terhadap 
perilaku. Jadi dapat disimpulkan bahwa niat dapat memediasi pengaruh sikap, norma subyektif, dan kontrol keperilakuan terhadap perilaku pelaku UKM dalam melakukan pemasaran melalui e-commerce di Kota Malang.

\section{Pembahasan}

Hasil analisis menunjukkan sikap berpengaruh terhadap niat. Sikap positif konsumen berupa tingginya kepercayaan terhadap atribut serta penilaian baik terhadap hasil evaluasi seluruh atribut obyek akan menguatkan niat dalam pemasaran melalui $e$ commerce. Hasil penelitian ini mendukung hasil penelitian terdahulu yang dilakukan oleh Marcoux (1997), Halveka (2003), Hrubes et al. (2001), Davis et al. (2002), Rhodes (2003), Jostein et al., (2003), dan Fayolle et al. (2005).

Norma subyektif juga berpengaruh terhadap niat. Norma subyektif yang semakin kuat terutama dari aspek motivasi dari unsur keluarga maupun orang lain akan semakin menguatkan niat dalam pemasaran melalui e-commerce. Hasil penelitian ini mendukung hasil penelitian terdahulu yang dilakukan oleh Marcoux (1997), Hrubes et al. (2001), Davis et al. (2002), Rhodes (2003), Jostein et al. (2003), dan Fayolle et al. (2005).

Hasil analisis lainnya menunjukkan variabel kontrol keperilakuan berpengaruh terhadap niat. Kontrol keperilakuan cukup tinggi yang tercermin pada terbentuknya keyakinan dan kekuatan diri akan menguatkan niat dalam pemasaran melalui $e$ commerce. Hasil penelitian ini mendukung hasil penelitian terdahulu yang dilakukan oleh Marcoux (1997), Hrubes et al. (2001), Davis et al. (2003), Jostein et al. (2003), dan Fayolle et al. (2005).

Niat juga berpengaruh terhadap perilaku. Niat dalam pemasaran melalui $e$ commerce sangat terukur dari niat eksploratif berupa selalu mencari informasi tentang pemasaran melalui e-commerce dan selalu mencari informasi mengenai pemasaran melalui e-commerce sesuai dengan diinginkan, sehingga niat dalam pemasaran melalui e-commerce akan meningkatkan perilaku.

Penelitian ini juga menemukan bahwa niat memediasi pengaruh sikap, norma subyektif, dan kontrol keperilakuan terhadap perilaku pelaku UKM dalam pemasaran melalui e-commerce oleh UKM di Kota Malang. Hal tersebut bermakna bahwa pengaruh sikap, norma subyektif, dan kontrol keperilakuan terhadap perilaku pelaku-pelaku pelaku UKM dalam pemasaran melalui e-commerce oleh UKM di Kota Malang akan lebih kuat apabila dimediasi oleh niat.

\section{Kesimpulan}

Hasil penelitian ini menunjukkan bahwa sikap positif konsumen, norma subyektif yang semakin kuat dan kontrol keperilakuan yang cukup tinggi akan menguatkan niat dalam pemasaran melalui $e$ commerce. Hal ini berarti tingginya kepercayaan terhadap atribut serta penilaian baik terhadap hasil evaluasi seluruh atribut obyek, aspek motivasi dari unsur keluarga maupun orang lain dan terbentuknya keyakinan dan kekuatan diri akan semakin menguatkan niat dalam pemasaran melalui e-commerce.

Selain itu, niat dalam pemasaran melalui e-commerce sangat terukur dari niat eksploratif berupa selalu mencari informasi tentang pemasaran melalui e-commerce dan selalu mencari informasi mengenai pemasaran melalui e-commerce sesuai dengan diinginkan, maka niat dalam pemasaran melalui e-commerce akan meningkatkan perilaku. Hubungan positif sikap, norma subyektif, dan kontrol keperilakuan serta niat terhadap perilaku UKM dalam pemasaran melalui e-commerce membuat niat mampu memediasi pengaruh sikap, norma subyektif, dan kontrol keperilakuan terhadap perilaku pelaku UKM dalam pemasaran melalui e-commerce.

\section{DAFTAR PUSTAKA}

Ajzen, I. (1991). The theory of planned behavior. Organizational Behavior and Human Decision Processes, 50, 179- 
211. https://doi.org/10.1016/0749 5978(91)90020-t

Ajzen, I. (2020). The theory of planned behavior: Frequently asked questions. Human Behavior \& Emerging Technologies, 1-11. https://doi.org/10.1002/hbe2.195

Ajzen, I., \& Sheikh, S. (2013). Action versus inaction: Anticipated affect in the theory of planned behavior. Journal of Applied Social Psychology, 43(1), 155162. https://doi.org/10.1111/j.15591816.2012.00989.x

Armitage, C. J., \& Conner, M. (2001). Efficacy of the theory of planned behavior: A meta-analytic review. British Journal of Social Psychology, 40, 471-499

Bosnjak, M., Ajzen, I., \& Schmidt, P. (2020). The theory of planned behavior: Selected recent advances and applications. Europe's Journal of Psychology, 16(3), 352-356. https://doi.org/10.5964/ejop.v16i3.3107

Darsono T, D., Susana, E., Prihantono, E, P. (2018). Small medium business marketing through E-Commerce (Theory of Planned Behavior Approach) Indonesian. IOSR Journal of Business and Management (IOSR$J B M)$, 20(10)

http://dx.doi.org/10.9790/487X2010045866

Darsono, J.T., Susana, E., Prihantono, E. Y. (2019). Strategic policies for small and medium businesses in marketing through e-commerce. Entrepreneurship and Sustainability Issues 7(2): 12301245.

http://doi.org/10.9770/jesi.2019.7.2(30)

Davis, L. \& Ajzen. (2002). The decision of African American students to complete high school: An application of the theory of planned behavior. Journal of Educational Psychology, Vol. 94, No. 4, 810-819.

Fayolle, A. \& Gailly. (2005). Using The Theory Of Planned Behaviour to Assess Entrepreneurship Teaching Programmes. Center for Research in
Change, Innovation and Strategy. Perancis.

Gillholm, R., Erdeus, J. \& Gärling, T. (2001). The effect of choice on intentionbehavior consistency. Scandinavian Journal of Psychology, in press.

Gollwitzer, P. M. \& Oettingen, G. (1998). The emergence and implementation of health goals. Psychology and Health, 13, 687-715.

Gollwitzer, P. M. \& Schaal, B. (1998). Metacognition in action: The importance of implementation intentions. Personality and Social Psychology Review, 2, 124-136.

Gollwitzer, P. M. (1999). Implementation intentions. Simple effects of simple plans. American Psychologist, 54, 493501.

Hair, J.F., et al. (2010). Multivariate data analysis. (7th edition). New Jersey: Pearson Education Inc.

Havelka, D. (2003). Students Beliefs and Attitudes Toward Information Technology. Department of Decision Sciences and MIS. Miami University.

Hrubes, Ajzen, \& Daigle. (2001). Predicting Hunting Intentions and Behavior: An Application of the Theory of Planned Behavior. Department of Agriculture Forest Service's Northeastern Research Station.

Jostein, R., Marianne, T., \& Bas V. (2003). Measuring implementations in the context of the theory of planned behavior. Scandinavian Journal of Psychology 44(2):87-95. DOI: 10.1111/1467-9450.00325

Kuncoro, M. (2008). Tujuh Tantangan UKM di Tengah Krisis Global. Harian Bisnis Indonesia 21 Oktober 2008.

La Barbera, F., \& Ajzen, I. (2020). Control interactions in the theory of planned behavior: Rethinking the role of subjective norm. Europe's Journal of Psychology, 16(3), 401-417. https://doi.org/10.5964/ejop.v16i3.2056

Loren, W., Eunro, L., Katherine J. Reynolds, K. A. \& Klik. (2020). The theory of planned behavior and the social 
identity approach: A new look at group processes and social norms in the context of student binge drinking. Europe's Journal of Psychology. Vol. 16(3), 357-383, https://doi.org/10.5964/ejop.v16i3.1900 Marcoux, J. \& Shope1. J. T. (1997). Application Of The Theory Of Planned Behavior To Adolescent Use And Misuse Of Alcohol. Health Education Research, Theory \& Practice, Vol.12 No.3.

Rhodes R. E. (2003). Modelling The Theory Of Planned Behaviour And Past Behaviour. Psychology, Health \& Medicine, Vol. 8, No. 1.

Solimun, M. S. (2002). Structural Equation Modeling (SEM) Lisrel dan Amos. Fakultas MIPA. Universitas Brawijaya. Malang.

Sutton, S. (1998). Predicting and explaining intentions and behavior: How well are we doing? Journal of Applied Social Psychology, 28, 1317-1338.

Zemore, S. E., \& Ajzen, I. (2014). Predicting substance abuse treatment completion using a new scale based on the theory of planned behavior. Journal of Substance Abuse Treatment, 46(2), 174-182.

https://doi.org/10.1016/j.jsat.2013.06.0

11 